\title{
Lysobacter panaciterrae sp. nov., isolated from soil of a ginseng field
}

\author{
Correspondence \\ Wan-Taek Im \\ wandra@kaist.ac.kr \\ Hee-Mock Oh \\ heemock@kribb.re.kr
}

\author{
Leonid N. Ten, ${ }^{1}$ Hae-Min Jung, ${ }^{2}$ Wan-Taek $I m,{ }^{2}$ Soon-Ae Yoo, ${ }^{1}$ \\ Hee-Mock $\mathrm{Oh}^{3}$ and Sung-Taik Lee ${ }^{2}$ \\ ${ }^{1}$ Department of Biology and Medicinal Science, Pai Chai University, 14 Yeonja-1-Gil, Seo-Gu, \\ Daejeon 302-735, Republic of Korea \\ ${ }^{2}$ Department of Biological Sciences, Korea Advanced Institute of Science and Technology, 373-1, \\ Guseong-dong, Yuseong-gu, Daejeon 305-701, Republic of Korea \\ ${ }^{3}$ Korean Collection for Type Cultures (KCTC), Korea Research Institute of Bioscience and \\ Biotechnology, 52 Oeundong, Yusong-gu, Daejeon 305-333, Republic of Korea
}

The genus Lysobacter, belonging to the family Xanthomonadaceae, class Gammaproteobacteria, was established by Christensen \& Cook (1978) with the description of four species: Lysobacter enzymogenes, L. antibioticus, $L$. brunescens and L. gummosus. They are Gram-negative, aerobic, gliding organisms with a high DNA G $+\mathrm{C}$ content and develop colonies that are highly mucoid and cream, pink or yellow-brown in colour. Members of the genus are strongly proteolytic and characteristically lyse a variety of micro-organisms such as Gram-positive bacteria (including actinomycetes), filamentous fungi, yeasts and green algae, as well as nematodes. L. enzymogenes was shown to be a potential biocontrol agent for plant fungal pathogens (Folman et al., 2004; Kilic-Ekici \& Yuen, 2003). In addition to the four species mentioned above, at the time of writing the genus Lysobacter includes nine other recognized species, namely Lysobacter capsici (Park et al., 2008), L. concretionis (Bae et al., 2005), L. daejeonensis (Weon et al., 2006), L. defluvii (Yassin et al., 2007), L. koreensis (Lee et al., 2006), L. niabensis and L. niastensis (Weon et al., 2007), L. spongiicola (Romanenko et al., 2008) and L. yangpyeon-

The GenBank/EMBL/DDBJ accession number for $16 \mathrm{~S}$ rRNA gene sequence of strain Gsoil $068^{\top}$ is $A B 245359$. gensis (Weon et al., 2006). Except L. spongiicola, all members of the genus Lysobacter have been isolated from terrestrial environments, mainly from soil.

During the course of a study on the culturable aerobic and facultatively anaerobic bacterial community living in the soil of a ginseng field in Pocheon Province (South Korea), a large number of bacterial strains were isolated. In the present study, we have characterized one of these isolates, namely strain Gsoil $068^{\mathrm{T}}$. Phenotypic, chemotaxonomic and phylogenetic analyses established that this isolate was affiliated with the genus Lysobacter. The data obtained also suggest that the isolate represents a novel species of the genus.

A soil sample was taken from the rhizosphere of 5-year-old ginseng plants. This was a slightly acidic ( $\mathrm{pH}$ 6.0), rich, sandy soil with a friable and well-aerated texture. The soil sample was thoroughly suspended in $50 \mathrm{mM}$ phosphate buffer ( $\mathrm{pH} 7.0$ ), serially diluted in the same buffer and suitable 10-fold dilutions were spread onto modified R2A solid medium containing the following (per litre distilled water): $0.25 \mathrm{~g}$ tryptone, $0.25 \mathrm{~g}$ peptone, $0.25 \mathrm{~g}$ yeast extract, $0.125 \mathrm{~g}$ malt extract, $0.125 \mathrm{~g}$ beef extract, $0.25 \mathrm{~g}$ Casamino acids, 0.25 g soytone, 0.5 g glucose, 0.3 g soluble 
starch, $0.2 \mathrm{~g}$ xylan, $0.3 \mathrm{~g}$ sodium pyruvate, $0.3 \mathrm{~g} \mathrm{~K}_{2} \mathrm{HPO}_{4}$, $0.05 \mathrm{~g} \mathrm{MgSO}_{4}, 0.05 \mathrm{~g} \mathrm{CaCl}_{2}$ and $15 \mathrm{~g}$ agar. The plates were incubated at $30{ }^{\circ} \mathrm{C}$ for 2 weeks. Single colonies appearing on the plates were purified by transferring them onto fresh plates of the modified R2A agar and incubating again. One isolate, Gsoil $068^{\mathrm{T}}$, was cultured routinely on R2A agar (Difco) at $30{ }^{\circ} \mathrm{C}$ and was preserved in a glycerol solution $(20 \%, w / v)$ at $-70{ }^{\circ} \mathrm{C}$.

The Gram reaction was determined by using the nonstaining method, as described by Buck (1982). Cell morphology was observed under a Nikon light microscope at $\times 1000$ magnification, with cells grown on R2A agar for 2 days at $30{ }^{\circ} \mathrm{C}$. Catalase and oxidase tests were performed as outlined by Cappuccino \& Sherman (2002). Tests for anaerobic growth, nitrate and nitrite reduction and assimilation of 16 amino acids and 31 other compounds (except for substrates included in API 20NE and API ID $32 \mathrm{GN}$ kits) were performed as described by Ten et al. (2006). In addition, biochemical tests were carried out by using API 20E, API 20NE and API ID 32GN test kits according to the manufacturer's instructions (bioMérieux). Tests for degradation of DNA (by using DNase agar from Scharlau, with DNase activity by flooding plates with $1 \mathrm{M}$ $\mathrm{HCl}$ ), casein, chitin, starch (Atlas, 1993), lipids (Kouker \& Jaeger, 1987), xylan and cellulose (Ten et al., 2004) were performed and evaluated after 7 days. Growth at different temperatures $\left(4,10,15,25,30,37,42,45\right.$ and $\left.50{ }^{\circ} \mathrm{C}\right)$ and $\mathrm{pH}$ (4.5-10.0 at intervals of $0.5 \mathrm{pH}$ units) was assessed after 5 days incubation. Salt tolerance was tested on R2A agar supplemented with $1-10 \%(\mathrm{w} / \mathrm{v}) \mathrm{NaCl}$ after 5 days incubation. Growth on nutrient agar, trypticase soy agar (TSA) and MacConkey agar was also evaluated (at $30^{\circ} \mathrm{C}$ ).

Cells of strain Gsoil $068^{\mathrm{T}}$ were aerobic, Gram-negative, rodshaped, non-spore-forming and non-motile but having gliding activity. The isolate grew on nutrient agar, TSA and MacConkey agar. It did not require $\mathrm{NaCl}$ for growth but was able to tolerate up to $3 \%(\mathrm{w} / \mathrm{v}) \mathrm{NaCl}$. Strain Gsoil $068^{\mathrm{T}}$ was able to grow at $15-45{ }^{\circ} \mathrm{C}$. The isolate hydrolysed gelatin, indicating proteolytic activity; this was also observed for the type strains of all recognized Lysobacter species. The ability to degrade chitin and starch, which is present in some Lysobacter species (Christensen \& Cook, 1978; Weon et al., 2006, 2007), was not observed in the novel strain. Strain Gsoil $068^{\mathrm{T}}$ was negative for arginine dihydrolase, urease, indole production and the assimilation of D-ribose, inositol, gluconate, adipate, phenylacetate, itaconate, suberate, malonate, lactate, 4-hydroxybenzoate, salicin and L-alanine, consistent with data for most recognized Lysobacter species (Romanenko et al., 2008). Phenotypic and chemotaxonomic characteristics that differentiate strain Gsoil $068^{\mathrm{T}}$ from recognized Lysobacter species are listed in Table 1. In particular, strain Gsoil $068^{\mathrm{T}}$ could be differentiated readily from most Lysobacter species based on its ability to grow at $45{ }^{\circ} \mathrm{C}$, to utilize caprate and to produce catalase.

For phylogenetic analysis, genomic DNA was extracted by using a commercial genomic DNA extraction kit (Solgent).
PCR-mediated amplification of the 16S rRNA gene and sequencing of the purified PCR product were carried out according to Kim et al. (2005). The nearly complete $16 \mathrm{~S}$ rRNA gene sequence of strain Gsoil $068^{\mathrm{T}}$ was compiled by using SeqMan software (DNASTAR). The 16S rRNA gene sequences of related taxa were obtained from the GenBank database. Multiple alignments were performed by using the CLUSTAL X program (Thompson et al., 1997). Gaps were edited in the BioEdit program (Hall, 1999). Evolutionary distances were calculated by using Kimura's two-parameter model (Kimura, 1983). Phylogenetic trees were constructed by using the neighbour-joining (Saitou \& Nei, 1987) and maximum-parsimony (Fitch, 1971) methods in the MEGA4 program (Tamura et al., 2007), with bootstrap values based on 1000 replications (Felsenstein, 1985).

The 16S rRNA gene sequence of strain Gsoil $068^{\mathrm{T}}$ was a continuous stretch of $1489 \mathrm{bp}$. Comparative 16S rRNA gene sequence analyses showed that the novel strain was phylogenetically affiliated with species of the genus Lysobacter. In the phylogenetic tree (Fig. 1) based on the neighbour-joining algorithm, strain Gsoil $068^{\mathrm{T}}$ appeared within the genus Lysobacter and formed a branch with $L$. brunescens ATCC $29482^{\mathrm{T}}$. On the basis of 16S rRNA gene sequence similarity data, strain Gsoil $068^{\mathrm{T}}$ was related most closely to L. brunescens ATCC $29482^{\mathrm{T}}$ and L. gummosus ATCC $29489^{\mathrm{T}}(96.1 \%)$. Levels of $16 \mathrm{~S}$ rRNA gene sequence similarity to the type strains of other recognized species within the class Gammaproteobacteria were below $96.0 \%$. The generally accepted criteria for delineating bacterial species state that strains showing $16 \mathrm{~S}$ rRNA gene sequence dissimilarity above $3 \%$ or showing a level of DNA-DNA relatedness below $70 \%$ (as measured by hybridization) are considered as belonging to separate species (Wayne et al., 1987; Stackebrandt \& Goebel, 1994). The data presented here thus indicated that strain Gsoil $068^{\mathrm{T}}$ was not related to any previously described member of the genus Lysobacter at the species level.

For measurement of the $\mathrm{G}+\mathrm{C}$ content of the chromosomal DNA, the genomic DNA of strain Gsoil $068^{\mathrm{T}}$ was extracted and purified as described by Moore \& Dowhan (1995). The $\mathrm{G}+\mathrm{C}$ content of the DNA was determined as described by Mesbah et al. (1989) after degradation of the DNA to nucleosides by $\mathrm{P} 1$ nuclease and alkaline phosphatase and subsequent separation of the nucleosides by reversed-phase HPLC. Isoprenoid quinones were extracted with chloroform/methanol $(2: 1, \mathrm{v} / \mathrm{v})$, evaporated under a vacuum and re-extracted in $n$-hexane/water $(1: 1, \mathrm{v} / \mathrm{v})$. The crude $\mathrm{n}$-hexane/quinone solution was purified by using Sep-Pak Vac Cartridges Silica (Waters) and was analysed subsequently by HPLC, as described by Hiraishi et al. (1996). The cellular fatty acid profile of strain Gsoil $068^{\mathrm{T}}$ was determined following growth on R2A agar (Difco) for $48 \mathrm{~h}$ at $28{ }^{\circ} \mathrm{C}$. The cellular fatty acids were saponified, methylated and extracted according to the protocol of the Sherlock Microbial Identification System (MIDI). The fatty acid methyl esters were then analysed by GC (model 6890; Hewlett Packard) by using the Microbial 
Table 1. Differential phenotypic characteristics between strain Gsoil $068^{\top}$ and the type strains of recognized $L y s o b a c t e r$ species

Strains: 1, Gsoil $068^{\mathrm{T}}$ (data from the present study); 2, L. brunescens ATCC 29482 ${ }^{\mathrm{T}}$ (data in columns 2, 3, 5 and 6 from Swings \& Christensen, 1989); 3, L. gummosus ATCC $29489^{\mathrm{T}}$; 4, L. capsici KCTC $22007^{\mathrm{T}}$ (Park et al., 2008); 5, L. antibioticus DSM 2044 ${ }^{\mathrm{T}}$; 6, L. enzymogenes DSM 2043 ${ }^{\mathrm{T}}$; 7 , L. niastensis DSM $18481^{\mathrm{T}}$ (Weon et al., 2007); 8, L. concretionis DSM $16239^{\mathrm{T}}$ (Bae et al., 2005); 9, L. yangpyeongensis $\mathrm{KACC}_{11407^{\mathrm{T}}}$ (Weon et al., 2006); 10, L. daejeonensis KACC $11406^{\mathrm{T}}$ (Weon et al., 2006); 11, L. niabensis DSM 18244 ${ }^{\mathrm{T}}$ (Weon et al., 2007); 12, L. spongiicola JCM $14760^{\mathrm{T}}$ (Romanenko et al., 2008); 13, L. koreensis KCTC $12204^{\mathrm{T}}$ (Lee et al., 2006); 14, L. defluvii DSM $18482^{\mathrm{T}}$ (Yassin et al., 2007). All strains are positive for gelatin hydrolysis and negative for urease, indole production and the assimilation of inositol. + , Positive; $(+)$, weakly positive; \pm , variable; - , negative; ND, no data available.

\begin{tabular}{|c|c|c|c|c|c|c|c|c|c|c|c|c|c|c|}
\hline Characteristic & 1 & 2 & 3 & 4 & 5 & 6 & 7 & 8 & 9 & 10 & 11 & 12 & 13 & 14 \\
\hline \multicolumn{15}{|l|}{ Growth at/on: } \\
\hline $5{ }^{\circ} \mathrm{C}$ & - & + & - & - & + & + & - & + & - & - & + & + & - & - \\
\hline $45^{\circ} \mathrm{C}$ & + & + & - & - & - & - & - & - & - & - & - & - & - & - \\
\hline MacConkey agar & + & - & - & - & - & + & - & ND & - & - & - & - & + & - \\
\hline Gliding motility & + & + & + & + & + & + & + & + & - & - & - & - & $\mathrm{ND}$ & $\mathrm{ND}$ \\
\hline Nitrate reduction & - & - & - & ND & + & - & + & + & - & + & - & - & - & - \\
\hline Aesculin hydrolysis & + & + & + & + & + & + & + & - & - & + & - & - & - & - \\
\hline Starch hydrolysis & - & - & - & - & - & - & + & - & + & - & + & - & - & - \\
\hline Catalase & - & + & + & + & + & + & + & + & - & $(+)$ & + & + & + & + \\
\hline Oxidase & + & + & $\mathrm{ND}$ & + & + & + & + & + & + & + & + & + & - & + \\
\hline$\beta$-Galactosidase & - & - & \pm & - & + & \pm & \pm & - & - & - & - & - & - & - \\
\hline $\mathrm{NaCl}$ tolerance (range, \%) & $0-3$ & $0-1$ & $0-2$ & $0-2$ & $0-2$ & $0-2$ & $0-1$ & ND & $0-0.5$ & $0-3$ & $0-1$ & $0-6$ & $0-1$ & $0-6$ \\
\hline \multicolumn{15}{|l|}{ Assimilation of: ${ }^{*}$} \\
\hline Acetate & + & - & $(+)$ & ND & + & $(+)$ & - & + & - & + & - & - & - & $\mathrm{ND}$ \\
\hline $\mathrm{N}$-Acetyl-D-glucosamine & + & - & + & - & + & + & + & - & - & - & - & - & - & - \\
\hline Glycogen & + & - & + & ND & + & + & - & $(+)$ & + & + & - & - & - & ND \\
\hline Maltose & + & - & + & - & + & + & + & - & - & + & - & - & - & - \\
\hline Melibiose & - & - & + & ND & - & + & - & - & - & - & - & - & - & ND \\
\hline L-Rhamnose & - & - & - & - & - & - & - & - & - & - & - & - & + & - \\
\hline Sucrose & - & - & + & - & - & + & - & - & - & - & - & - & - & ND \\
\hline L-Arabinose & - & - & - & - & - & - & - & - & - & - & - & - & + & - \\
\hline Caprate & + & - & - & ND & - & - & - & - & - & - & - & - & - & - \\
\hline D-Sorbitol & - & - & - & - & - & - & - & - & - & - & - & - & + & - \\
\hline D-Mannose & + & - & + & $\mathrm{ND}$ & + & + & - & - & - & - & - & - & - & - \\
\hline D-Mannitol & - & - & - & - & - & - & - & - & - & - & - & - & + & - \\
\hline Valerate & + & - & $(+)$ & $\mathrm{ND}$ & + & + & - & + & - & + & - & - & + & ND \\
\hline D-Glucose & + & - & + & - & + & + & $(+)$ & - & - & + & - & - & - & - \\
\hline L-Histidine & - & - & - & ND & + & $(+)$ & + & - & - & - & - & - & - & $\mathrm{ND}$ \\
\hline Citrate & + & - & - & + & - & + & - & - & - & - & - & - & + & + \\
\hline 3-Hydroxybutyrate & + & - & + & $\mathrm{ND}$ & + & + & - & + & + & + & - & - & - & $\mathrm{ND}$ \\
\hline 5-Ketogluconate & - & - & - & - & - & - & - & - & - & - & - & + & - & ND \\
\hline Malate & + & - & + & ND & + & + & - & - & - & - & - & - & - & - \\
\hline L-Proline & - & - & + & $\mathrm{ND}$ & + & + & - & + & - & - & - & - & - & $\mathrm{ND}$ \\
\hline DNA G $+\mathrm{C}$ content $(\mathrm{mol} \%)$ & 67.0 & 67.7 & 65.7 & 65.4 & 69.2 & 69.0 & 66.6 & 63.8 & 67.3 & 61.7 & 62.5 & 69.0 & 68.9 & 67.1 \\
\hline
\end{tabular}

${ }^{\star}$ Using API 20NE and API ID 32GN tests.

Identification software package (Sasser, 1990). Duplicate experiments were performed to give a range of values. Polar lipids were extracted and examined by twodimensional TLC according to Minnikin et al. (1984).

The fatty acid profile of strain Gsoil $068^{\mathrm{T}}$ (Table 2) was compared with those of the type strains of recognized Lysobacter species. The major components were branched fatty acids, namely iso- $\mathrm{C}_{15: 0}$, iso- $\mathrm{C}_{17: 1} \omega 9 c$, iso- $\mathrm{C}_{17: 0}$ and iso- $\mathrm{C}_{11: 0} 3-\mathrm{OH}$, a profile that is typical of members of the genus Lysobacter (Bae et al., 2005; Weon et al., 2006, 2007; Romanenko et al., 2008). However, some minor qualitative and quantitative differences in the fatty acids were observed between strain Gsoil $068^{\mathrm{T}}$ and its phylogenetically closest relatives. In particular, strain Gsoil $068^{\mathrm{T}}$ differed from recognized Lysobacter species based on its higher content of iso- $\mathrm{C}_{17: 0}$ and iso- $\mathrm{C}_{17: 1} \omega 9 \mathrm{c}$ and lower content of iso- $\mathrm{C}_{16: 0}$. Strain Gsoil $068^{\mathrm{T}}$ contained ubiquinone Q-8 as the major respiratory quinone. The polar lipids detected in strain Gsoil $068^{\mathrm{T}}$ were phosphatidylethanolamine, diphosphati- 


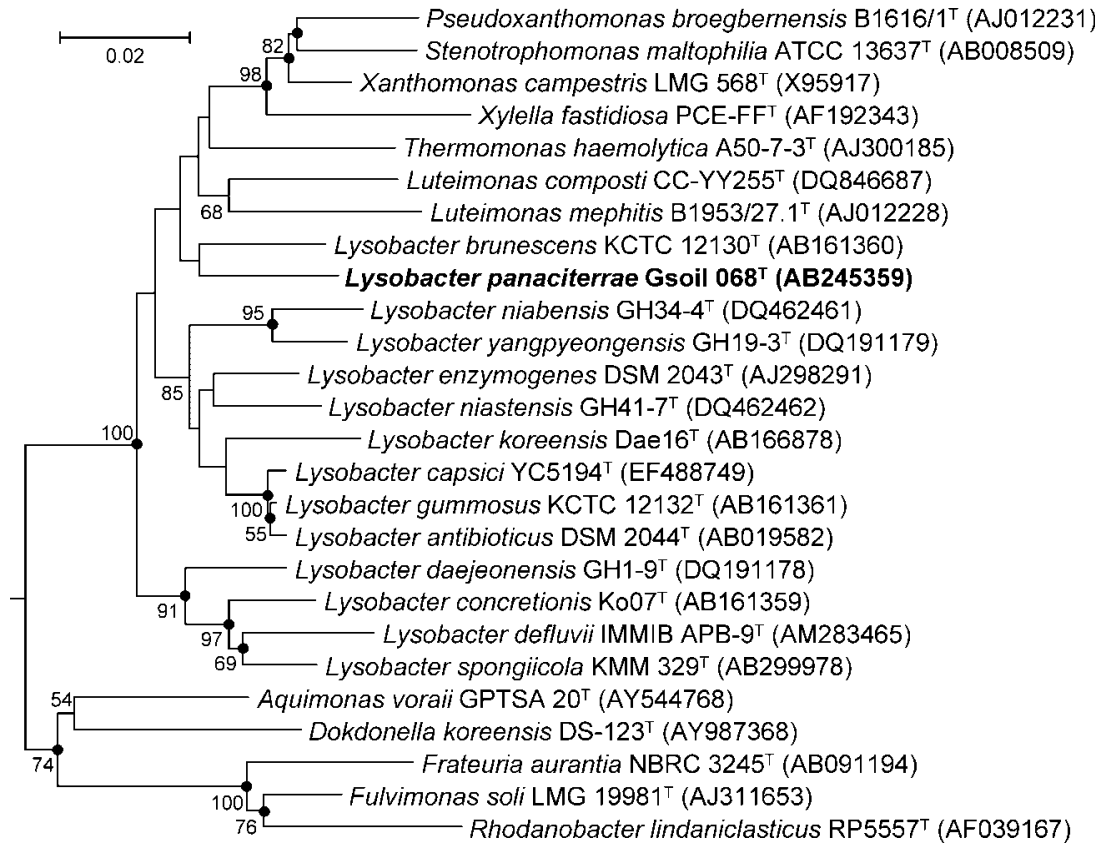

Fig. 1. Phylogenetic relationship between strain Gsoil $068^{\top}$ and the type strains of recognized Lysobacter species and other related species within the class Gammaproteobacteria. The tree was constructed by using the neighbour-joining method based on 16S rRNA gene sequences. Bootstrap values (expressed as percentages of 1000 replications) of more than $50 \%$ are shown at branch points. The sequence of Pseudomonas aeruginosa LMG $1242^{\top}$ (GenBank accession no. Z76651) was used as an outgroup (not shown). Filled circles indicate that the corresponding notes were also recovered in the tree generated with the maximum-parsimony algorithm. Bar, 0.02 substitutions per nucleotide position. dylglycerol, phosphatidylglycerol, one unknown aminolipid and one unknown lipid. These data are in good agreement with those for other members of the genus Lysobacter (Bae et al., 2005; Weon et al., 2006, 2007; Park et al., 2008; Romanenko et al., 2008; Yassin et al., 2007). The genomic DNA G + C content of strain Gsoil $068^{\mathrm{T}}$ was $67.0 \mathrm{~mol} \%$, which lies within the range observed for members of the genus Lysobacter (61.7-69.2 mol\%).

The phenotypic and phylogenetic data presented here indicate that strain Gsoil $068^{\mathrm{T}}$ belongs to the genus Lysobacter. Phylogenetic distinctiveness confirmed that this isolate represent a species that is distinct from recognized Lysobacter species. Strain Gsoil $068^{\mathrm{T}}$ can be differentiated from phylogenetically related Lysobacter species based on several phenotypic characteristics (Table 1). Therefore, on the basis of the data presented, strain Gsoil $068^{\mathrm{T}}$ is considered to represent a novel species of the genus Lysobacter, for which the name Lysobacter panaciterrae sp. nov. is proposed.

\section{Description of Lysobacter panaciterrae sp. nov.}

Lysobacter panaciterrae (pa.na.ci.ter'rae. N.L. n. Panax-acis scientific name for ginseng; L. n. terra soil; N.L. gen. n. panaciterrae of soil of a ginseng field).

Colonies grown on R2A agar plates for 3 days are 1.5$3.0 \mathrm{~mm}$ in diameter, smooth, circular, non-glossy and cream-coloured, but take on a weak brownish yellow swarming form after 1 month. The optimum temperature for growth is $30^{\circ} \mathrm{C}$. The $\mathrm{pH}$ range for growth is $\mathrm{pH} 5.0$ 8.5, with an optimum between $\mathrm{pH} 6.5$ and 7.0. Able to hydrolyse gelatin and casein, but not chitin, starch, cellulose, xylan, lipids or DNA. Nitrate is not reduced to nitrite and nitrite is not reduced to nitrogen gas. The following substrates are utilized for growth: D-glucose, Dmannose, D-lyxose, L-xylose, $N$-acetyl-D-glucosamine, cellobiose, maltose, trehalose, aesculin, acetate, caprate, citrate, formate, DL-3-hydroxybutyrate, malate, pyruvate, succinate, valerate, glycogen, L-aspartate, L-glutamine and L-tyrosine. The following substrates are not utilized for growth: Lfructose, D- and L-arabinose, L-fucose, D-galactose, Lrhamnose, L-sorbose, D-ribose, D-xylose, salicin, lactose, melibiose, sucrose, raffinose, amygdalin, inulin, dextran, propionate, maleate, fumarate, phenylacetate, benzoate, 3hydroxybenzoate, 4-hydroxybenzoate, lactate, malonate, glutarate, tartrate, itaconate, adipate, suberate, oxalate, 2ketogluconate, 5-ketogluconate, gluconate, dulcitol, inositol, D-adonitol, D-mannitol, D-sorbitol, xylitol, methanol, ethanol, glycerol, urea, L-alanine, L-arginine, L-asparagine, Lcysteine, L-glutamate, L-histidine, glycine, L-isoleucine, Lleucine, L-lysine, L-methionine, L-phenylalanine, L-proline, L-serine, L-threonine, L-tryptophan and L-valine. Positive for tryptophan deaminase and the Voges-Proskauer test. Production of arginine dihydrolase, lysine decarboxylase, ornithine decarboxylase, urease, $\beta$-galactosidase, hydrogen sulfide and indole is negative. Acid is produced from D-glucose, but not from melibiose, amygdalin, L-arabinose, D-mannitol, inositol, D-sorbitol, L-rhamnose or sucrose. Ubiquinone Q-8 is the predominant quinone. Phosphatidylethanolamine, diphosphatidylglycerol and phosphatidylglycerol are the main polar lipids. The major fatty acids are iso- $\mathrm{C}_{15: 0}$, iso- $\mathrm{C}_{17: 1} \omega 9 c$, iso- $\mathrm{C}_{17: 0}$ and iso- $\mathrm{C}_{11: 0} 3-\mathrm{OH}$. The $\mathrm{G}+\mathrm{C}$ content of the genomic DNA of the type strain is $67.0 \mathrm{~mol} \%$. 
Table 2. Cellular fatty acid profiles of strain Gsoil $068^{\top}$ and type strains of recognized Lysobacter species

Strains: 1, Gsoil $068^{\mathrm{T}}$ (data from the present study); 2, L. brunescens ATCC 29482 ${ }^{\mathrm{T}}$; 3, L. gummosus ATCC 29489 ${ }^{\mathrm{T}}$; 4, L. capsici KCTC 22007 ${ }^{\mathrm{T}}$ (Park $^{\text {(P) }}$ et al., 2008); 5, L. antibioticus DSM 2044 $;$; , L. enzymogenes DSM 2043 ${ }^{\mathrm{T}} ; 7$, L. niastensis DSM $18481^{\mathrm{T}} ; 8$, L. concretionis DSM $16239^{\mathrm{T}}$; 9 , L. yangpyeongensis KACC $11407^{\mathrm{T}}$; 10, L. daejeonensis KACC $11406^{\mathrm{T}}$; 11, L. niabensis DSM $18244^{\mathrm{T}}$; 12, L. spongiicola JCM $14760^{\mathrm{T}}$ (Romanenko et al., 2008); 13, L. koreensis KCTC $12204^{\mathrm{T}}$; 14, L. defluvii DSM $18482^{\mathrm{T}}$ (Yassin et al., 2007). Data are from Weon et al. (2007) unless indicated otherwise. All strains were grown on R2A agar for $48 \mathrm{~h}$ at $28{ }^{\circ} \mathrm{C}$, except L. capsici KCTC $22007^{\mathrm{T}}$ (TSA, $\left.48 \mathrm{~h}, 28{ }^{\circ} \mathrm{C}\right)$, L. spongiicola JCM $14760^{\mathrm{T}}(\mathrm{R} 2 \mathrm{~A}$ agar, $72 \mathrm{~h}, 28{ }^{\circ} \mathrm{C}$ ) and L. defluvii DSM $18482^{\mathrm{T}}$ (BHI broth, 1 week, $37{ }^{\circ} \mathrm{C}$ ). Values are percentages of total fatty acids;,$-<1 \%$ or not detected.

\begin{tabular}{|c|c|c|c|c|c|c|c|c|c|c|c|c|c|c|}
\hline Fatty acid & 1 & 2 & 3 & 4 & 5 & 6 & 7 & 8 & 9 & 10 & 11 & 12 & 13 & 14 \\
\hline $\mathrm{C}_{14: 0}$ & - & - & - & 1.9 & 1.1 & 1.0 & - & - & - & - & - & - & - & - \\
\hline$C_{16: 0}$ & 5.2 & 1.5 & 6.0 & 10.8 & 8.0 & 8.6 & - & 1.6 & 3.1 & 1.4 & 1.1 & - & - & 2.9 \\
\hline $\mathrm{C}_{17: 0}$ cyclo & - & - & 1.0 & - & 7.2 & 6.2 & - & 1.9 & - & - & - & - & - & 3.2 \\
\hline iso- $\mathrm{C}_{10: 0}$ & - & - & - & - & - & - & - & - & - & - & 1.0 & - & 1.1 & - \\
\hline iso- $\mathrm{C}_{11: 0}$ & 3.8 & 5.9 & 3.8 & 2.3 & 3.1 & 3.4 & 4.1 & 5.7 & 4.3 & 3.7 & 6.4 & 9.5 & 5.3 & 1.8 \\
\hline iso- $\mathrm{C}_{12: 0}$ & - & & - & - & - & - & - & - & 1.1 & 2.0 & 1.3 & - & 1.1 & - \\
\hline iso- $\mathrm{C}_{14: 0}$ & - & 3.7 & - & - & 1.3 & 1.4 & 4.2 & 2.3 & 4.5 & 11.2 & 8.7 & 3.3 & 4.0 & - \\
\hline iso- $\mathrm{C}_{15: 0}$ & 29.5 & 19.6 & 25.2 & 23.3 & 24.9 & 20.5 & 21.9 & 33.6 & 14.5 & 13.1 & 12.7 & 23.0 & 12.5 & 40.9 \\
\hline iso- $\mathrm{C}_{16: 0}$ & 3.4 & 23.5 & 5.7 & - & 10.3 & 13.8 & 23.3 & 20.4 & 27.5 & 33.7 & 23.7 & 32.5 & 26.3 & 19.3 \\
\hline iso- $\mathrm{C}_{17: 0}$ & 16.0 & 2.3 & 7.8 & 3.7 & 3.4 & 2.9 & 1.3 & 4.1 & 1.9 & - & 1.6 & 2.8 & 1.8 & 11.1 \\
\hline anteiso- $\mathrm{C}_{15: 0}$ & 4.5 & 2.6 & 5.5 & - & 3.8 & 3.8 & 3.8 & 1.2 & 5.1 & 3.2 & 5.9 & - & - & - \\
\hline anteiso- $\mathrm{C}_{17: 0}$ & 1.4 & - & 1.4 & - & - & - & - & - & 1.1 & - & - & - & - & - \\
\hline $\mathrm{C}_{10: 0} 3-\mathrm{OH}$ & - & - & - & - & - & 1.1 & - & - & - & - & - & - & - & - \\
\hline iso- $\mathrm{C}_{11: 0} 3-\mathrm{OH}$ & 6.9 & 7.2 & 9.7 & 3.8 & 8.0 & 6.6 & 8.0 & 6.9 & 5.5 & 6.0 & 9.3 & 15.5 & 9.0 & 7.2 \\
\hline iso- $\mathrm{C}_{12: 0} 3-\mathrm{OH}$ & - & - & - & - & - & - & - & - & 1.0 & - & - & - & - & - \\
\hline iso- $\mathrm{C}_{15: 1}$ AT 5 & - & - & 1.7 & - & 1.0 & - & 1.6 & - & 3.1 & - & 3.4 & - & 4.4 & - \\
\hline iso- $\mathrm{C}_{15: 1} \mathrm{~F}$ & - & 1.7 & - & - & - & - & - & 3.2 & - & 3.2 & - & - & - & - \\
\hline iso- $\mathrm{C}_{16: 1} \mathrm{H}$ & - & 1.5 & - & - & - & - & 1.3 & - & 1.1 & 2.6 & 1.0 & - & 2.1 & - \\
\hline $\mathrm{C}_{16: 1} \omega 11 c$ & - & - & 4.5 & 2.2 & 4.1 & - & - & - & 2.2 & - & 1.0 & - & - & - \\
\hline $\mathrm{C}_{16: 1} \omega 7 c$ alcohol & - & - & 1.7 & - & 1.6 & - & 4.5 & - & 8.8 & - & 7.8 & - & 10.8 & - \\
\hline iso- $\mathrm{C}_{17: 1} \omega 9 c$ & 23.1 & 15.5 & 12.2 & - & 6.4 & 4.7 & 10.9 & 15.1 & 6.7 & 6.7 & 10.0 & 13.2 & 16.7 & 5.8 \\
\hline $\mathrm{C}_{18: 1} \omega 7 c$ & - & - & 2.5 & 6.5 & 1.7 & 3.3 & - & - & - & - & - & - & - & - \\
\hline Summed feature $4^{*}$ & 4.8 & 9.5 & 6.4 & 20.4 & 8.3 & 15.8 & 6.5 & - & 3.3 & 6.1 & 2.0 & - & 1.4 & - \\
\hline ECL $11.799 \dagger$ & 1.4 & - & 1.8 & - & 2.0 & 1.5 & 1.4 & - & - & - & - & - & - & - \\
\hline
\end{tabular}

${ }^{\star}$ Summed features represent groups of two or three fatty acids that could not be separated by GLC with the MIDI system. Summed feature 4 comprised iso- $\mathrm{C}_{15: 0} 2-\mathrm{OH}$ and/or $\mathrm{C}_{16: 1} \omega 7 \mathrm{c}$.

†Unknown fatty acids have no name listed in the peak library file of the MIDI system and therefore cannot be identified; ECL, equivalent chain length.

The type strain, Gsoil $068^{\mathrm{T}} \quad\left(=\mathrm{KCTC} 12601^{\mathrm{T}}=\mathrm{DSM}\right.$ $\left.17927^{\mathrm{T}}\right)$, was isolated from soil from a ginseng field in Pocheon Province, South Korea.

\section{Acknowledgements}

This work was supported by the 21C Frontier Microbial Genomics and Application Center Program, Ministry of Science \& Technology, Republic of Korea.

\section{References}

Atlas, R. M. (1993). Handbook of Microbiological Media. Edited by L. C. Parks. Boca Raton, FL: CRC Press.

Bae, H.-S., Im, W.-T. \& Lee, S.-T. (2005). Lysobacter concretionis sp. nov., isolated from anaerobic granules in an upflow anaerobic sludge blanket reactor. Int J Syst Evol Microbiol 55, 1155-1161.

Buck, J. D. (1982). Nonstaining ( $\mathrm{KOH})$ method for determination of Gram reactions of marine bacteria. Appl Environ Microbiol 44, 992-993.
Cappuccino, J. G. \& Sherman, N. (2002). Microbiology: a Laboratory Manual, 6th edn. Menlo Park, CA: Benjamin/Cummings.

Christensen, P. \& Cook, F. D. (1978). Lysobacter, a new genus of nonfruiting, gliding bacteria with a high base ratio. Int J Syst Bacteriol 28, 367-393.

Felsenstein, J. (1985). Confidence limits on phylogenies: an approach using the bootstrap. Evolution 39, 783-791.

Fitch, W. M. (1971). Toward defining the course of evolution: minimum change for a specific tree topology. Syst Zool 20, 406-416.

Folman, L. B., De Klein, M. J. E. M., Postma, J. \& van Veen, J. A. (2004). Production of antifungal compounds by Lysobacter enzymogenes isolate 3.1T8 under different conditions in relation to its efficacy as a biocontrol agent of Pythium aphanidermatum in cucumber. Biol Control 31, 145-154.

Hall, T. A. (1999). BioEdit: a user-friendly biological sequence alignment editor and analysis program for Windows 95/98/NT. Nucleic Acids Symp Ser 41, 95-98.

Hiraishi, A., Ueda, Y., Ishihara, J. \& Mori, T. (1996). Comparative lipoquinone analysis of influent sewage and activated sludge by high- 
performance liquid chromatography and photodiode array detection. J Gen Appl Microbiol 42, 457-469.

Kilic-Ekici, O. \& Yuen, G. Y. (2003). Induced resistance as a mechanism of biological control by Lysobacter enzymogenes strain C3. Biol Control 93, 1103-1110.

Kim, M. K., Im, W.-T., Ohta, H., Lee, M. \& Lee, S.-T. (2005). Sphingopyxis granuli sp. nov., a $\beta$-glucosidase-producing bacterium in the family Sphingomonadaceae in $\alpha-4$ subclass of the Proteobacteria. J Microbiol 43, 152-157.

Kimura, M. (1983). The Neutral Theory of Molecular Evolution. Cambridge: Cambridge University Press.

Kouker, G. \& Jaeger, K.-E. (1987). Specific and sensitive plate assay for bacterial lipases. Appl Environ Microbiol 53, 211-213.

Lee, J. W., Im, W.-T., Kim, M. K. \& Yang, D.-C. (2006). Lysobacter koreensis sp. nov., isolated from a ginseng field. Int J Syst Evol Microbiol 56, 231-235.

Mesbah, M., Premachandran, U. \& Whitman, W. B. (1989). Precise measurement of the $\mathrm{G}+\mathrm{C}$ content of deoxyribonucleic acid by highperformance liquid chromatography. Int J Syst Bacteriol 39, 159-167.

Minnikin, D. E., O’Donnell, A. G., Goodfellow, M., Alderson, G., Athalye, M., Schaal, A. \& Parlett, J. H. (1984). An integrated procedure for the extraction of bacterial isoprenoid quinones and polar lipids. J Microbiol Methods 2, 233-241.

Moore, D. D. \& Dowhan, D. (1995). Preparation and analysis of DNA. In Current Protocols in Molecular Biology, chapter 2, pp. 2-11. Edited by F. M. Ausubel, R. Brent, R. E. Kingston, D. D. Moore, J. G. Seidman, J. A. Smith \& K. Struhl. New York: Wiley.

Park, J. H., Kim, R., Aslam, Z., Jeon, C. O. \& Chung, Y. R. (2008), Lysobacter capsici sp. nov., with antimicrobial activity, isolated from the rhizosphere of pepper, and emended description of the genus Lysobacter. Int J Syst Evol Microbiol 58, 387-392.

Romanenko, L. A., Uchino, M., Tanaka, N., Frolova, G. M. \& Mikhailov, V. V. (2008). Lysobacter spongiicola sp. nov., isolated from a deep-sea sponge. Int J Syst Evol Microbiol 58, 370-374.

Saitou, N. \& Nei, M. (1987). The neighbor-joining method: a new method for reconstructing phylogenetic trees. Mol Biol Evol 4, 406425.

Sasser, M. (1990). Identification of bacteria through fatty acid analysis. In Methods in Phytobacteriology, pp. 199-204. Edited by Z. Klement, K. Rudolph \& D. C. Sands. Budapest: Akademiai Kaido.
Stackebrandt, E. \& Goebel, B. M. (1994). Taxonomic note: a place for DNA-DNA reassociation and $16 \mathrm{~S}$ rRNA sequence analysis in the present species definition in bacteriology. Int J Syst Bacteriol 44, 846849.

Swings, J. \& Christensen, P. (1989). Genus Lysobacter Christensen and Cook 1978, 372 ${ }^{\mathrm{AL}}$. In Bergey's Manual of Systematic Bacteriology, vol. 3, pp. 2083-2089. Edited by J. T. Staley, M. P. Bryant, N. Pfennig \& J. G. Holt. Baltimore: Williams \& Wilkins.

Tamura, K., Dudley, J., Nei, M. \& Kumar, S. (2007). MEGA4: molecular evolutionary genetic analysis (MEGA) software version 4.0. Mol Biol Evol 24, 1596-1599.

Ten, L. N., Im, W.-T., Kim, M.-K., Kang, M.-S. \& Lee, S.-T. (2004). Development of a plate technique for screening of polysaccharidedegrading microorganisms by using a mixture of insoluble chromogenic substrates. J Microbiol Methods 56, 375-382.

Ten, L. N., Liu, Q.-M., Im, W.-T., Lee, M., Yang, D.-C. \& Lee, S.-T. (2006). Pedobacter ginsengisoli sp. nov., a DNase-producing bacterium isolated from soil of a ginseng field in South Korea. Int J Syst Evol Microbiol 56, 2565-2570.

Thompson, J. D., Gibson, T. J., Plewniak, F., Jeanmougin, F. \& Higgins, D. G. (1997). The CLUSTAL_X windows interface: flexible strategies for multiple sequence alignment aided by quality analysis tools. Nucleic Acids Res 25, 4876-4882.

Wayne, L. G., Brenner, D. J., Colwell, R. R., Grimont, P. A. D., Kandler, O., Krichevsky, M. I., Moore, L. H., Moore, W. E. C., Murray, R. G. E. \& other authors (1987). International Committee on Systematic Bacteriology. Report of the ad hoc committee on reconciliation of approaches to bacterial systematics. Int J Syst Bacteriol 37, 463-464.

Weon, H.-Y., Kim, B.-Y., Baek, Y.-K., Yoo, S.-H., Kwon, S.-W., Stackebrandt, E. \& Go, S.-J. (2006). Two novel species, Lysobacter daejeonensis sp. nov. and Lysobacter yangpyeongensis sp. nov., isolated from Korean greenhouse soils. Int J Syst Evol Microbiol 56, 947-951.

Weon, H.-Y., Kim, B.-Y., Kim, M.-K., Yoo, S.-H., Kwon, S.-W., Go, S.-J. \& Stackebrandt, E. (2007). Lysobacter niabensis sp. nov. and Lysobacter niastensis sp. nov., isolated from greenhouse soils in Korea. Int J Syst Evol Microbiol 57, 548-551.

Yassin, A. F., Chen, W.-M., Hupfer, H., Siering, C., Kroppenstedt, R. M., Arun, A. B., Lai, W.-A., Shen, F.-T., Rekha, P. D. \& Young, C. C. (2007). Lysobacter defluvii sp. nov., isolated from municipal solid waste. Int J Syst Evol Microbiol 57, 1131-1136. 